\title{
PENGARUH PEMILIHAN KEPALA DAERAH TERHADAP PASAR TENAGA KERJA: ANALISIS SEKTOR FORMAL DAN INFORMAL LEVEL KABUPATEN/KOTA DI PULAU JAWA
}

\section{Beni Teguh Gunawan ${ }^{1}$}

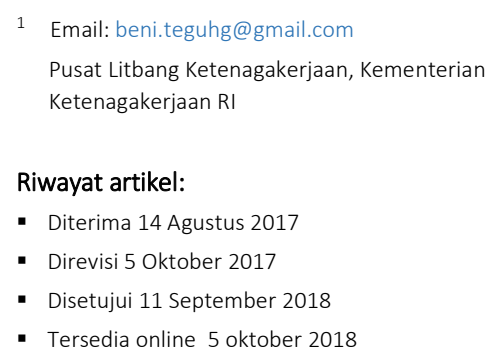

\begin{abstract}
The objective of this paper is to determine the effect of local election (pilkada) to formal and informal sector, especially in Java. Local elections in Indonesia are conducted at district and provincial levels. Incumbent candidate tends to use their power to control the fiscal sector in the region to improve their electability. One of the efforts is improving the regional economy performance that will positively impact new job creation as predicted in the trade-off concept of the Phillips curve. Empirical results indicate that district/municipal election positively influences the absorption of informal sector workers. A year before the district-level elections, it is expected that there is an increase of informal sector workers, while formal sector reduces. Different results shown in the provincial elections, that one year before election has no impact on the formal sector. When district/municipal and provincial elections are held in the same year, the expected impact on informal sector workers decreased while the formal sector increased. When the incumbent candidate participates in the election, the absorption of informal workers is expected to increase with no effect on the formal employment sector.
\end{abstract}

\begin{abstract}
Abstrak
Tujuan dari penelitian ini adalah untuk mengetahui pengaruh pelaksanaan pemilihan kepala daerah (pilkada) terhadap sektor formal dan informal, khususnya di Pulau Jawa. Pilkada di Indonesia dilakukan di tingkat kabupaten/kota dan provinsi. Calon kepala daerah petahana cenderung menggunakan kekuatannya dalam mengendalikan sektor fiskal di daerah untuk meningkatkan elektabilitasnya. Salah satu upaya yang dilakukan adalah dengan meningkatkan kinerja perekonomian daerah yang akan berdampak pada penciptaan lapangan-lapangan kerja baru, sebagaimana konsep trade-off dalam kurva Phillips. Hasil empiris menunjukkan bahwa pilkada tingkat kabupaten/kota berpengaruh signifikan terhadap penyerapan tenaga kerja sektor informal. Satu tahun sebelum pelaksanaan pilkada tingkat kabupaten/kota tenaga kerja sektor informal meningkat, sebaliknya tenaga kerja sektor formal berkurang. Hasil berbeda ditunjukkan pada pilkada tingkat provinsi, yakni satu tahun sebelum pelaksanaan pilkada tidak ditemukan dampak pada sektor formal. Saat pilkada tingkat provinsi dan kabupaten/kota dilaksanakan pada tahun yang sama, penyerapan tenaga kerja sektor informal berkurang sedangkan sektor formal bertambah. Jika ditinjau dari keikutsertaan calon petahana, pada pilkada provinsi yang diikuti calon petahana diperkirakan akan meningkatkan penyerapan tenaga kerja informal dan tidak ditemukan pengaruh terhadap tenaga kerja formal.
\end{abstract}




\section{PENDAHULUAN}

Fenomena politik tidak dapat dilepaskan dari fenomena sosial ekonomi, baik dalam lingkup makro maupun mikro. Salah satu fenomena yang terpengaruh dengan adanya peristiwa politik adalah sektor ketenagakerjaan. Literatur yang menghubungkan sektor ketenagakerjaan dengan politik relatif telah banyak dilakukan sebelumnya. Studi yang dilakukan oleh Mechtel dan Potrafke (2013) di Jerman menemukan bahwa sebelum pemilihan umum (pemilu) penyerapan tenaga kerja cenderung tinggi dalam jangka pendek untuk menarik simpati pemilih pada saat sebelum pelaksanaan pemilu. Charles dan Stephens (2013) menggunakan data level negara bagian di Amerika Serikat untuk mengetahui pengaruh jumlah pekerja dan upah terhadap tingkat partisipasi dalam pemilihan presiden dan gubernur. Hasilnya adalah upah berpengaruh negatif dan signifikan terhadap tingkat partisipasi pada pemilihan gubernur akan tetapi tidak berpengaruh terhadap pemilihan presiden. Dahlberg dan Mörk (2011) melakukan penelitian sejenis menggunakan data employment dan pemilu tingkat kota di Finlandia dan Swedia. Pada tahun saat pemilu dilaksanakan, penyerapan tenaga kerja penuh waktu di kedua negara tersebut cenderung meningkat. Pola hubungan pilkada dan penyerapan tenaga kerja di studi sebelumnya menunjukkan bahwa pemerintah daerah menggunakan kekuatan fiskal untuk menaikkan popularitas menjelang pelaksanaan pemilu (Khemani, 2004; Drazen dan Eslava, 2006).

Studi-studi sebelumnya umumnya menggunakan pendekatan employment secara umum tanpa membedakan sektor karena di negara maju sektor formal mendominasi sektor informal. Sektor informal diduga dapat memberikan dampak yang signifikan terhadap fluktuasi jumlah employment, khususnya di negara berkembang. Hal ini karena di negara berkembang sektor informal memiliki persentase yang jauh lebih besar dibandingkan dengan sektor formal, yakni hampir 70\% pekerja berada di sektor informal (Bosch \& Esteban-Pretel, 2012). Pekerjaan di sektor informal cenderung lebih mudah untuk diperoleh, akan tetapi rentan terhadap risiko kerja karena merupakan kelompok pekerja yang tidak terlindungi (Hohberg \& Lay, 2015). Indonesia, menurut data Sakernas BPS bulan Agustus 2015, memiliki 76,12\% pekerja sektor informal. Sektor informal cenderung lebih mudah untuk diintervensi karena tidak berdasarkan pada kontrak kerja maupun tunduk pada aturan ketenagakerjaan. Pemberi kerja lebih mudah untuk mendapatkan pekerja secara informal, dan pekerja informal lebih mudah untuk diberhentikan. Selain sektor informal, penelitian ini juga akan fokus pada sektor formal serta dengan mempertimbangkan kondisi-kondisi ketenagakerjaan umum.

Sektor ketenagakerjaan cenderung rentan terhadap kepentingan pihak-pihak tertentu, terlebih dengan tingginya pengangguran di negara berkembang. Alasan ekonomi menjadi penyebab para pengangguran lebih tertarik dengan calon kepala daerah yang memberikan janji untuk bekerja, sehingga relatif lebih mudah untuk menarik simpati melalui tawaran pekerjaan. Oleh karena itu, sektor ini menjadi salah satu komoditas yang menarik bagi calon kepala pemerintahan untuk menarik simpati calon pemilih (Lewis-Beck \& Paldam, 2000; Mueller, 2003). Tingginya frekuensi pemilihan kepala pemerintahan, baik di pusat maupun di daerah, sedikit banyak akan menyebabkan fluktuasi pada ketenagakerjaan, terlebih di Indonesia, pemilihan kepala pemerintahan dilakukan setiap lima tahun sekali. Pemilihan pimpinan eksekutif yang meliputi pemilihan presiden dan wakil presiden, gubernur dan wakil gubernur, serta bupati/walikota dan wakil bupati/wakil walikota. Selain pemilihan pimpinan eksekutif, pemilihan umum juga dilakukan setiap lima tahun sekali untuk memilih wakil rakyat dalam parlemen yang berperan sebagai lembaga legislatif baik untuk tingkatan nasional, provinsi, maupun kabupaten/kota. Pemilihan legislatif dilakukan pada tahun yang sama dengan pemilihan presiden. Sedangkan pemilihan kepala daerah dilakukan pada saat masa pemerintahan kepala daerah berakhir. Sejak tahun 2016, pemilihan di tingkat kabupaten/kota dan provinsi dilakukan secara serentak, sedangkan pemilihan umum tingkat nasional terakhir diadakan pada tahun 2014.

Pengaruh pemilihan kepala daerah (pilkada) terhadap ketenagakerjaan diduga berbeda pada saat sebelum hingga menjelang diadakannya pemilihan. Coelho, Veiga, dan Veiga (2006) menemukan bahwa di Portugal, political business cycle (PBC) berpengaruh sangat signifikan terhadap sektor ketenagakerjaan. Tingkat employment meningkat tajam dalam satu tahun hingga menjelang pemilu dilaksanakan. Calon kepala pemerintahan akan berlomba-lomba untuk menarik simpati pemilih sedikit demi sedikit pada tahun-tahun sebelum pemilihan dan semakin besar pada saat menjelang pemilihan. Di Indonesia, tingkatan terendah pemilihan kepala daerah adalah kabupaten/kota untuk memilih bupati/walikota/wakil bupati/wakil walikota, kemudian tingkatan provinsi untuk memilih gubernur/wakil gubernur dan tingkatan nasional untuk memilih presiden dan wakil presiden. Penyelenggara pemilihan umum di Indonesia adalah Komisi Pemilihan Umum (KPU) yang berada di tingkat nasional hingga kabupaten/kota. 
Penelitian ini bertujuan untuk menangkap fenomena pengaruh diadakannya pilkada, khususnya selama periode pilkada parsial di Indonesia terhadap penyerapan tenaga kerja di sektor formal dan informal. Periode yang ingin dilihat dalam penelitian ini adalah tahun 2010 hingga 2015. Periode tersebut dipilih karena sejak tahun 2016 pilkada di Indonesia dilaksanakan secara serentak. Fenomena yang dilihat pada tingkatan kabupaten/kota sebagai unit terkecil pelaksanaan pilkada pada satu tahun hingga menjelang pelaksanaan.

\section{TINJAUAN PUSTAKA}

\section{a. Kerangka Teori}

Teori political business cycle (PBC) dan teori partisan (PT) menjelaskan bagaimana perilaku pemerintahan dalam menghadapi pilkada terkait dengan ketenagakerjaan. Teori PBC menggambarkan bagaimana calon kepala daerah dan kepala daerah petahana memaksimumkan peluang untuk terpilih. Peluang terpilih diasumsikan sebagai bentuk kepuasan voter terhadap kinerja calon kepala daerah. Teori PBC menggambarkan upaya politisi dalam meningkatkan kepuasan voter dengan mempertimbangkan teori dalam kurva Phillips yang menunjukkan hubungan antara pengangguran dengan inflasi (Nordhaus, 1975; Rogoff, 1990; Shi \& Svensson, 2006). Kurva Philips menggambarkan hubungan negatif antara pengangguran dan inflasi dalam jangka pendek.

Asumsi yang digunakan dalam PT adalah non rational expectation, yaitu masing-masing partai politik akan berusaha memaksimumkan utility. Model PBC dapat digunakan pada tingkatan nasional maupun tingkat lokal. Model ini memprediksi bahwa calon kepala daerah petahana dapat meningkatkan pengeluaran sebelum pemilihan untuk mendapatkan simpati yang lebih besar. Calon kepala daerah petahana diasumsikan memiliki kekuasaan untuk mengintervensi kondisi perekonomian di daerahnya. Hal ini dapat terjadi karena kontrol terhadap fiskal daerah ada di dalam kekuasaan petahana. Upaya untuk membangun opini positif terhadap calon petahana memiliki kemungkinan lebih besar dibandingkan dengan calon non-petahana. Kondisi perekonomian yang meningkat dalam jangka pendek ditandai dengan peningkatan inflasi. Perekonomian yang meningkat juga akan mempengaruhi sektor ketenagakerjaan karena semakin banyak lapangan pekerjaan yang tersedia. Akan tetapi, kondisi inflasi yang tinggi dalam jangka panjang akan berdampak buruk pada perekonomian (Mankiw, 2001).

Atas dasar tersebut, calon kepala daerah petahana cenderung akan berusaha untuk meningkatkan perekonomian dalam jangka pendek dan akan membiarkan perekonomian business as usual dalam jangka panjang, kecuali kepala daerah yang menganggap voter adalah aset pada pemilihan kepala daerah di masa depan. Lowongan pekerjaan yang meningkat sesaat akan memberikan opini positif terhadap calon kepala daerah. Jika ditinjau dari sektor pekerjaan yang tercipta, di negara berkembang seperti di Indonesia sektor informal sangat dominan. Sektor informal diduga sebagai sektor yang paling terpengaruh dengan kondisi menjelang pemilihan umum mengingat sifat dari sektor informal yang sering disebut sebagai unregulated jobs karena cenderung tidak mengikuti regulasi dan tidak terkendala birokrasi pemerintahan (Ulyssea, 2010). Sementara pada sektor formal, beberapa aturan pada ketenagakerjaan harus diterapkan. Salah satu contohnya adalah mempertimbangkan besaran upah minimum.

Profil ketenagakerjaan Indonesia secara umum terdapat pada data Survei Angkatan Kerja Nasional (Sakernas) yang dilakukan BPS dua kali setiap tahun pada bulan Februari dan Agustus. Penelitian ini menggunakan Sakernas bulan Agustus untuk penyeragaman data, sedangkan data tentang pemilihan diperoleh dari Komisi Pemilihan Umum (KPU). Pengaruh pilkada terhadap pola ketenagakerjaan sektor formal dan informal dilihat secara agregat kabupaten/kota pada saat $\mathrm{t}-\mathrm{l}$, di mana $\mathrm{t}$ adalah tahun penyelenggaraan pemilihan umum baik tingkat kabupaten/kota dan provinsi. Analisis empiris menggunakan analisis data panel dengan variabel dependen persentase pekerja yang bekerja di sektor informal dan formal. Daerah yang akan dianalisis dalam studi ini adalah wilayah Jawa karena Jawa merupakan konsentrasi terbesar penduduk di Indonesia. Sedangkan, pemilihan tahun adalah tahun 2010-2015, karena periode tersebut mewakili rentang waktu selama dan sebelum pemilihan umum secara nasional. Pada kondisi tertentu, pilkada untuk tingkatan kabupaten/kota dan provinsi dilaksanakan bersamaan, yang tergantung pada berakhirnya masa jabatan masing-masing kepala daerah.

\section{b. Definisi formal dan informal}

Pembahasan yang mendalam mengenai pekerja sektor formal dan informal perlu dilakukan untuk mengetahui definisi yang pasti dalam membedakan kelompok pekerja sektor formal dan informal. Tinjauan terhadap tenaga kerja formal secara tidak langsung akan memberikan gambaran tentang definisi pekerja informal, demikian juga sebaliknya. Ditinjau dari tingkat kompleksitas, pekerja sektor informal memiliki sejumlah hal yang tidak dimiliki 
sektor formal. Tinjauan ini akan lebih fokus pada pekerja informal, sehingga kategori yang tidak termasuk dalam definisi informal dapat diartikan masuk ke dalam sektor formal.

Pada kerangka yang dikembangkan Hussmanns (2004) dijabarkan contoh kelompok pekerja tertentu yang dipekerjakan pada sektor informal dan tenaga kerja informal yang dipekerjakan selain pada sektor informal yaitu:

a. Mereka yang dipekerjakan di sektor informal, meliputi:

1) Pekerja yang berusaha sendiri pada perusahaan miliknya;

2) Pemberi kerja pada perusahaan informal;

3) Pekerja pada sektor informal;

4) Pekerja keluarga yang bekerja pada perusahaan informal;

5) Anggota jaringan produsen informal/koperasi informal.

b. Pekerja informal yang bekerja di luar sektor informal, khususnya:

1) Pekerja pada sektor formal yang tidak terlindungi oleh perlindungan sosial, tidak terdaftar secara resmi, atau tidak mendapatkan hak pekerja seperti gaji tahunan atau cuti sakit yang tetap dibayar;

2) Pekerja rumah tangga bayaran yang tidak terlindungi dan tidak mendapat hak-hak pekerja seperti di atas;

3) Anggota rumah tangga yang dipekerjakan di perusahaan formal.

Sejumlah negara juga menyertakan pekerja yang memproduksi barang secara khusus digunakan untuk kegunaan akhir di rumah tangga mereka, seperti pertanian subsistem/gurem untuk konsumsi sendiri, sebagai pekerja informal (Park, Wu, \& Du, 2012). Dari batasan kegiatan formal dan informal berdasarkan status pekerjaan dan jenis pekerjaan utama yang diterbitkan Badan Pusat Statistik, maka dapat dihitung jumlah masing-masing pekerja formal dan informal, yaitu:

a. Status pekerjaan berusaha dibantu buruh dibayar dan buruh/karyawan/pegawai seluruhnya merupakan pekerja formal;

b. Untuk mereka yang berstatus berusaha sendiri tanpa dibantu, pekerja bebas di pertanian dan non-pertanian dengan jabatan tenaga profesional, tenaga kepemimpinan, dan tenaga tata laksana merupakan pekerja formal, selain itu merupakan pekerja informal;

c. Mereka yang berstatus berusaha dibantu buruh tidak dibayar dengan jenis pekerjaan tenaga usaha pertanian, kehutanan perburuan, dan perikanan adalah pekerja informal, sisanya merupakan pekerja formal, kecuali jenis pekerjaan lainnya yang dapat termasuk sebagai pekerja formal maupun informal;

d. Pada status pekerja keluarga, semuanya masuk dalam ekonomi informal.

\section{c. Data}

Penelitian ini bertujuan untuk melihat dampak dari diadakannya pilkada baik pada tingkatan kabupaten/kota maupun provinsi terhadap kondisi pasar tenaga kerja di daerah tersebut. Pemilihan umum daerah untuk memilih bupati/walikota dan wakilnya serta gubernur dan wakilnya mulai dilakukan di Indonesia sejak tahun 2005. Sedangkan untuk pilkada serentak baru dilaksanakan sejak tahun 2016. Sebelum tahun 2016, pilkada dilaksanakan secara parsial selama beberapa gelombang di daerah-daerah yang masa pemerintahan kepala daerahnya telah habis. Sedangkan pada saat pemberlakuan sistem serentak, pilkada dibagi menjadi dua periode secara serentak di daerah yang masa pemerintahan kepala daerahnya telah berakhir.

Masa pemerintahan kepala daerah di Indonesia adalah 5 (lima) tahun dengan pilihan mencalonkan kembali pada periode berikutnya. Alasan tersebut juga menjadi alasan untuk pemilihan periode tahun 2010-2015 yang merupakan satu periode masa jabatan untuk bupati/walikota dan gubernur. Sebelum tahun 2017, pilkada dilakukan secara parsial berdasarkan kabupaten/kota dan provinsi. Baru sejak tahun 2017, berdasarkan Peraturan Komisi Pemilihan Umum (KPU) RI No. 3 tahun 2016, pilkada dilakukan secara serentak di seluruh kabupaten/kota dan provinsi yang masa jabatan kepala daerahnya telah usai. Informasi atas segala sesuatu tentang pemilihan daerah diperoleh dari KPU, sedangkan data pendukung untuk ketenagakerjaan diperoleh dari Sakernas. Penelitian ini menggunakan data Sakernas bulan Agustus karena data Agustus dianggap mewakili data ketenagakerjaan pada tahun berjalan. 
Tingkatan analisis yang dilihat adalah level agregat kabupaten/kota dan provinsi. Pemilihan umum tingkat nasional atau pemilu tidak disertakan dalam analisis karena dampaknya tidak dapat dibedakan per daerah, melainkan satu negara. Data ketenagakerjaan di Indonesia tersedia dalam Survei Angkatan Kerja Nasional (Sakernas) yang dilakukan dua kali dalam satu tahun oleh BPS. Data Sakernas tersedia pada bulan Februari dan Agustus. Sakernas merupakan survei tingkatan individu yang memiliki penimbang, sehingga dalam analisisnya data Sakernas dianggap bisa digunakan untuk mewakili data ketenagakerjaan secara nasional. Penelitian ini menggunakan data Sakernas Agustus karena secara sampel, Sakernas Agustus digunakan untuk estimasi Kab/Kota memiliki jumlah sampel lebih banyak mencapai 5.000 blok sensus (BS) + 15.000 BS sedangkan Februari digunakan untuk estimasi Provinsi dengan sampel mencapai 5.000 BS atau 50.000 rumah tangga (RMT)

Dampak yang ingin dilihat adalah periode satu tahun sebelum pilkada dilakukan. Penelitian ini mengadopsi model pada Coelho et al. (2006), yakni pengaruh yang dilihat adalah satu tahun hingga menjelang pilkada dilaksanakan. Selain itu, alasan mengapa dampak pilkada dilihat pada satu tahun sebelumnya adalah karena penelitian ini menggunakan data Sakernas edisi bulan Agustus. Pada beberapa kabupaten/kota tertentu, pilkada diadakan pada awal tahun, meskipun tidak menutup kemungkinan juga diadakan pada pertengahan dan akhir tahun. Sehingga jika dampaknya dilihat pada tahun yang sama dengan diadakannya pilkada dikhawatirkan justru kabupaten/kota tertentu telah selesai mengadakan pilkada. Profil ketenagakerjaan dalam data Sakernas dapat diketahui hingga tingkatan individu, sedangkan dalam analisis empiris agregasi data Sakernas dilakukan hingga tingkatan kabupaten/kota. Hal ini dikarenakan tingkatan terendah dalam pemilihan kepala daerah adalah kabupaten/kota, demikian pula berbagai indikator perekonomian terendah yang dapat diketahui di Indonesia.

Restriksi Sakernas dilakukan dengan mengeluarkan data non-Jawa. Jawa menjadi pokok bahasan dalam penelitian ini karena hampir 70\% perekonomian di Indonesia terjadi di Pulau Jawa. Fenomena sosial dan ekonomi diasumsikan dapat dijelaskan di sini karena keberagaman penduduk, kultur, dan budaya. Selain itu, $60 \%$ penduduk Indonesia menghuni pulau Jawa. Analisis data agregat tahun 2010 hingga 2015 dari hasil restriksi tersebut akan diperoleh jumlah pengamatan sebanyak 117 kabupaten/kota. Masing-masing kabupaten/kota tersebut diamati selama 6 tahun untuk mendapatkan data panel dengan total pengamatan sebanyak 702 pengamatan. Kabupaten Pangandaran tidak dimasukkan ke dalam analisis karena kabupaten tersebut merupakan hasil pemekaran dari Kabupaten Sukabumi sejak tahun 2012. Demikian juga dengan Kabupaten Bandung Barat, yang merupakan kabupaten hasil pemekaran dari Kabupaten Bandung sejak tahun 20ll. Tabel 3 menunjukkan statistik deskriptif dari variabel dependen dan independen yang meliputi variabel utama sektor formal.

Variabel dependen dalam penelitian ini adalah total penduduk yang bekerja sektor formal dan informal di masing-masing kabupaten/kota. Jumlah penduduk yang bekerja diperoleh dari angkatan kerja yang bekerja pada tahun tersebut. Data total penduduk yang bekerja diperoleh dengan mengagregasi data tingkatan individu Sakernas tahun 2010 hingga 2015. Sedangkan, variabel independen utama yang digunakan adalah dKab yang menunjukkan dummy pengaruh satu tahun sebelum diadakannya pemilihan kepala daerah tingkat kabupaten/kota, variabel dKab bernilai 1 pada saat satu tahun sebelum pilkada kabupaten/kota dan bernilai 0 untuk selainnya. Demikian pula untuk variabel dProv yang menunjukkan dummy pengaruh satu tahun diadakannya pemilihan kepala daerah tingkat provinsi, variabel dProv bernilai 1 pada saat satu tahun sebelum pilkada provinsi dan bernilai 0 untuk selainnya. Kedua variabel dummy tersebut juga akan diinteraksikan untuk mengetahui apakah pilkada tingkat kabupaten/kota dan provinsi dilaksanakan pada tahun yang sama, dummy interaksi tersebut bernilai 1 jika pilkada kabupaten/kota dan provinsi dilaksanakan pada tahun yang sama, serta 0 untuk selainnya. Salah satu variabel utama adalah PetProv yang menunjukkan dummy keikutsertaan calon kepala daerah petahana pada pemilihan kepala daerah selanjutnya, variabel PetProv bernilai 1 jika calon petahana di provinsi memutuskan untuk mengikuti pilkada pada periode selanjutnya dan bernilai 0 untuk selainnya. Dummy PetProv hanya digunakan pada saat pemilihan tingkat provinsi, hal ini dikarenakan pada tingkatan kabupaten/kota untuk periode pilkada 2010 hingga 2015 seluruh petahana mengikuti pilkada periode selanjutnya, sehingga dampak keikutsertaan calon petahana dan non-petahana tidak dapat diketahui.

Variabel kontrol yang menggambarkan kondisi perekonomian di kabupaten/kota yang digunakan dalam penelitian ini adalah Produk Domestik Regional Bruto (PDRB) berdasarkan harga konstan tahun dasar 2010. Variabel PDRB diperoleh dari publikasi BPS terkait profil masing-masing daerah. PDRB akan ditransformasi menjadi logaritma (ln_pdrb) untuk melihat pengaruhnya dalam persentase. Selain PDRB, variabel tenaga kerja sektor informal $\left(\ln _{-} \mathrm{I}\right)$, sektor formal $\left(\ln _{-} \mathrm{F}\right)$, penduduk usia kerja (ln_puk), jumlah angkatan kerja (ak), total penduduk bekerja (ln_total) bersumber dari data Sakernas dengan berbagai pendekatan dari beberapa butir pertanyaan. Sektor formal 
dan informal dapat diketahui dengan mengkombinasikan pertanyaan status/kedudukan pekerjaan utama dalam seminggu terakhir dan kelompok baku jabatan Indonesia. Rincian mengenai kelompok yang masuk dalam kategori formal dan informal telah dijelaskan dalam bagian sebelumnya. Variabel kontrol lain yang menjelaskan tingkat penyerapan tenaga kerja adalah upah minimum kabupaten/kota (ln_umk), penduduk usia kerja (ln_puk), jumlah angkatan kerja (ak), total penduduk bekerja (ln_total), serta variabel dummy interaksi PetProv yang menunjukkan bahwa pada pemilihan kepala daerah tingkat provinsi diikuti calon petahana.

\section{METODE PENELITIAN}

\section{a. Spesifikasi Empiris}

Metode analisis yang digunakan pada penelitian ini adalah analisis data panel. Menurut Wooldridge (2002), analisis data panel dapat menggunakan metode fixed effect, random effect atau pooled least square. Prosedur pemilihan salah satu model terbaik antara ketiga model tersebut menggunakan uji Hausman, Chow dan Lagrange Multiplier (LM). Uji Hausman digunakan untuk menentukan apakah model akan menggunakan fixed effect atau random effect, sedangkan uji LM digunakan untuk menentukan model terbaik antara random effect atau pooled least square. Uji Chow digunakan untuk menentukan model terbaik antara fixed effect atau pooled least square. Uji pemilihan model tersebut adalah sebagai berikut :

- $\quad$ F-Test/Chow Test

F-Test/Chow Test dilakukan untuk mendeteksi ada atau tidaknya efek individu, sehingga bisa diputuskan apakah model yang dipilih fixed effect atau pooled least square.

HO : Model Pooled Least Square

Hl : Model Fixed Effect

dengan uji statistik menggunakan distribusi $\mathrm{F}$ dengan formulasi sebagai berikut :

$F_{N-1, N T-N-T}=\frac{(R R S S-U R S S) /(N-1)}{U R S S /(N T-N-1)}$

Di mana RRSS = restricted residual sum square, URSS = unrestricted residual sum square, $\mathrm{N}=$ jumlah data cross section, dan $\mathrm{T}$ = jumlah data time series.

Jika Fstat > Ftabel, maka tolak Ho, yang artinya model terbaik adalah fixed effect. Jika Fstat < Ftabel, maka terima Ho, yang artinya model terbaik adalah pooled least square.

- Uji Langrange Multiplier (LM)

Pengujian Langrange Multiplier (LM) untuk random effects berdasarkan residual OLS dapat digunakan untuk pemilihan antara random effects atau pooled regression.

Hipotesisnya adalah :

HO : $\sigma_{u}^{2}=0$

$\mathrm{Hl}:{ }^{2}{ }_{u}^{2} \neq 0$

Jika HO ditolak, maka model terbaik yang digunakan adalah pooled regression.

- Hausman Test

Uji Hausman test dilakukan untuk mendeteksi adanya korelasi antara error dan variabel bebas, untuk memilih metode fixed effect atau random effect.

HO : random effect

$\mathrm{Hl}$ : fixed effect

Jika nilai tabel < Uji Hausman, artinya tidak ada korelasi yang terjadi antara error dan variabel bebas. Oleh karena itu tolak Ho, sehingga metode terbaik adalah fixed effect. Jika nilai tabel > Uji Hausman, artinya ada korelasi yang terjadi antara error dan variabel bebas. Oleh karena itu terima Ho, sehingga metode terbaik adalah random effect. 
TABEL-1. Penentuan Model Terbaik

\begin{tabular}{clll}
\hline No & Jenis Uji & Keputusan & Kesimpulan \\
\hline 1 & Uji Hausman & Tolak HO & Fixed effect \\
2 & Uji Chow & Tolak HO & Fixed effect \\
3 & Uji Lagrange Multiplier & Terima HO & $\begin{array}{l}\text { Random } \\
\text { effect }\end{array}$ \\
& (LM) & & \\
\hline
\end{tabular}

Catatan: Dari hasil pengolahan data Eviews 8 untuk Uji Chow dan hasil pengolahan data Stata 14 untuk uji Hausman dan LM

Hasil uji Hausman, Chow dan Lagrange Multiplier menunjukkan bahwa model fixed effect merupakan model terbaik yang dapat digunakan pada data dalam penelitian ini. Meskipun, dalam uji LM menunjukkan random effect merupakan model terbaik. Akan tetapi, jika dibandingkan dengan fixed effect, random effect belum dapat dikatakan model terbaik.

Model fixed effect, diasumsikan terdapat perbedaan diantara unit (individu). Perbedaan ini akan dilihat dari konstanta $\alpha \mathrm{i}$, yang merupakan parameter yang belum diketahui dan akan diestimasi. Misalkan yi dan Xi terdiri dari $\mathrm{T}$ observasi periode waktu dengan $\mathrm{i}$ unit. i merupakan kolom $\mathrm{T} \times \mathrm{l}$ yang terdiri dari angka $\mathrm{l}$, dan $\varepsilon i$ adalah vektor $\mathrm{T} \times 1$ random disturbances. Bentuk persamaan disusun sebagai berikut:

$$
y_{i t}=x_{i t}^{\prime} \beta+\alpha_{i}+\varepsilon_{i t}(2)
$$

Dari persamaan diatas secara umum, model ini memperkenalkan variabel dummy ke dalam model yang mengakibatkan perbedaan intercept dan antar individu. Model dalam persamaan ini selain dapat disebut sebagai persamaan regresi fixed effects juga disebut sebagai model least squares dummy variable (LSDV).

Pengaruh suatu fenomena yang dihubungkan dengan ketenagakerjaan seringkali menggunakan dengan variabel independen yang mewakili kondisi makro daerah (Hagedorn, Karahan, Manovskii, \& Mitman, 2013). Asumsikan Iit dan Fit adalah jumlah tenaga kerja sektor informal dan formal di suatu daerah i pada tahun ke-t dalam persen. Persamaan jumlah tenaga kerja masing-masing sektor dipengaruhi variabel independen ditunjukkan pada persamaan (3) dan (4)

$$
\begin{aligned}
& \ln _{-} I_{\mathrm{it}}=\beta_{0}+\beta_{1} d \mathrm{Kab}_{i t}+\beta_{2} \text { dProv }_{i t}+\beta_{3} d K a b * \operatorname{Prov}_{i t}+\beta_{7} \operatorname{PetProv}_{i t}+\gamma^{\prime} X+\varepsilon \\
& \ln _{-} F_{\mathrm{it}}=\beta_{0}+\beta_{1} d \text { Kab }_{i t}+\beta_{2} d \operatorname{Prov}_{i t}+\beta_{3} d K a b * \operatorname{Prov}_{i t}+\beta_{7} \operatorname{PetProv}_{i t}+\gamma^{\prime} X+\varepsilon
\end{aligned}
$$

Pada persamaan (3) dan (4) tenaga kerja sektor formal dan informal dipengaruhi oleh beberapa variabel independen.

Interpretasi model regresi fixed effect dapat dilakukan sebagaimana interpretasi dalam OLS. Efek parsial dapat diketahui dari nilai koefisien regresi masing-masing variabel. Pada variabel utama dKab, dProv ,dan PetProv yang merupakan variabel dummy, pengaruhnya dapat dilihat dengan melihat perbedaan pada saat variabel bernilai 0 dan 1 . 


\section{HASIL ANALISIS DAN PEMBAHASAN}

\section{a. Hasil Analisis Empiris}

Hasil analisis empiris menggunakan regresi data panel dengan metode fixed effect disajikan pada Tabel 2, persamaan (3) ditunjukkan oleh kolom penyerapan tenaga kerja sektor informal dan persamaan (4) ditunjukkan oleh kolom penyerapan tenaga kerja sektor formal. Tabel 2 membuktikan bahwa pengaruh pilkada terhadap penyerapan ketenagakerjaan relatif berbeda antara pilkada tingkatan provinsi dan kabupaten/kota. Pilkada kabupaten/kota berpengaruh terhadap penyerapan tenaga kerja sektor informal, di masa satu tahun sebelum diadakannya pilkada jumlah tenaga kerja sektor informal yang terserap sebanyak 3,39\% lebih banyak dibandingkan dengan masa setelah pilkada, sedangkan pengaruhnya terhadap sektor formal negatif, satu tahun sebelum pilkada kabupaten/kota mengurangi tenaga kerja formal sebesar 5,54\% lebih rendah dibandingkan dengan masa satu tahun setelah diadakannya pilkada.

Hasil yang berbeda ditunjukkan pada pilkada provinsi, yaitu satu tahun sebelum pelaksanaan pilkada tidak berpengaruh signifikan baik pada sektor formal maupun informal. Pada regresi panel dengan variabel dependen pekerja sektor informal, $p$-value variabel dummy sebelum pilkada provinsi bernilai 0,455 yang berarti tidak cukup bukti untuk mengatakan bahwa pilkada provinsi berdampak terhadap penyerapan tenaga kerja sektor informal. Pada saat pilkada provinsi dan kabupaten/kota dilakukan pada tahun yang sama, calon petahana provinsi juga berdampak positif dan signifikan pengaruhnya terhadap penyerapan tenaga kerja sektor informal ini. Jika calon petahana mengikuti pilkada akan menyerap sebanyak 6,58\% tenaga kerja informal dibandingkan dengan jika tidak diikuti calon petahana.

TABEL-2. Hasil Regresi fixed effect dengan variabel dependen persentase pekerja sektor informal (3) dan formal (4)

\begin{tabular}{lcccr}
\hline \multirow{2}{*}{$\begin{array}{c}\text { Variabel } \\
\text { Independen }\end{array}$} & \multicolumn{2}{c}{ Informal (3) } & \multicolumn{2}{c}{ Formal (4) } \\
\cline { 2 - 5 } & Koefisien & p-value & Koefisien & p-value \\
\hline kab & 0,03389 & 0,005 & $-0,0554$ & 0,001 \\
\hline prov & $-0,02455$ & 0,455 & $-0,0270$ & 0,551 \\
\hline kab ${ }^{*}$ prov & $-0,04779$ & 0,058 & 0,0828 & 0,017 \\
\hline petprov & 0,06582 & 0,029 & $-0,0332$ & 0,422 \\
\hline In_umk & 0,10116 & 0,027 & $-0,2422$ & 0,000 \\
\hline In_puk & $-0,08131$ & 0,166 & 0,1456 & 0,072 \\
\hline ak & 0,00015 & 0,006 & $-0,0001$ & 0,311 \\
\hline In_total & 1,11892 & 0,000 & 0,6982 & 0,000 \\
\hline In_pdrb & $-0,42538$ & 0,000 & 0,8381 & 0,000 \\
\hline cons & 1,73520 & 0,042 & $-4,6756$ & 0,000 \\
\hline
\end{tabular}

Sampel dalam regresi panel fixed effect sebanyak 702 observasi. Nilai R-squared persamaan (3) 85,69\%. Hasil uji $\mathrm{F}(12,573)=66,38$, Prob $>\mathrm{F}=.0000$. Nilai Rsquared persamaan (4) 88,94\%. Hasil uji $F(12,573)=45.98$, Prob $>F=0,0000$

Catatan: Dari hasil pengolahan data regresi data panel fixed effect menggunakan Eviews 8

Variabel independen pada Tabel 2 menunjukkan bahwa UMK berdampak positif dan signifikan terhadap penyerapan tenaga kerja sektor informal, setiap satu persen kenaikan UMK akan meningkatkan penyerapan tenaga kerja sektor informal sebesar $10,116 \%$. Variabel puk menunjukkan dampak yang tidak signifikan terhadap penyerapan tenaga kerja. Sementara variabel ak, dan ln_total berpengaruh positif dan signifikan, dengan setiap 10000 jiwa kenaikan angkatan kerja akan mengurangi penyerapan angkatan kerja sektor informal sebesar 1 hingga 2 orang, serta setiap satu persen kenaikan total pekerja akan berdampak kenaikan variabel dependen sebesar 1,1\%. Pengaruh berbeda ditunjukkan oleh variabel ln_pdrb, di mana dampaknya negatif dan signifikan, setiap satu persen kenaikan PDRB akan mengurangi penyerapan tenaga kerja sektor informal sebesar 4,25\%. 
Pada kasus penyerapan tenaga kerja sektor formal, hasil yang relatif berbeda diperoleh dari uji empiris. Pilkada tingkat kabupaten/kota berpengaruh signifikan terhadap variabel dependen. Akan tetapi, pengaruhnya negatif, yaitu setahun sebelum diadakannya pilkada tingkat kabupaten/kota penyerapan tenaga kerja sektor formal justru berkurang. Nilai koefisien regresi menunjukkan satu tahun sebelum diadakan pilkada tingkat kabupaten/kota, jumlah tenaga kerja sektor formal akan berkurang sebanyak 5,54\% dibandingkan dengan setelah pilkada. Variabel pilkada provinsi tidak signifikan pada persamaan regresi ini karena $\mathrm{p}$-value sebesar 0,551 yang berarti lebih besar daripada nilai derajat kesalahan yang ditetapkan yaitu sebesar 5\%.

Pada saat pilkada tingkat kabupaten/kota dan provinsi dilaksanakan pada tahun yang sama, jumlah penyerapan tenaga kerja sektor formal bertambah sebesar 8,28\% dibandingkan dengan pada saat pilkada kabupaten/kota dan provinsi dilakukan di tahun yang berbeda. Hal berbeda juga tampak pada variabel petprov, yakni pada sektor informal variabel petprov berpengaruh positif dan signifikan terhadap penyerapan tenaga kerja sedangkan pada persamaan regresi dengan variabel dependen tenaga kerja sektor formal, variabel petprov tidak berdampak signifikan terhadap penyerapan tenaga kerja. Hal ini berarti bahwa calon petahana yang ikut serta kembali dalam pilkada tidak berpengaruh terhadap penyerapan tenaga kerja sektor formal.

Variabel independen pada Tabel 2 menunjukkan bahwa UMK berdampak negatif dan signifikan terhadap penyerapan tenaga kerja sektor informal, setiap satu persen kenaikan UMK akan mengurangi penyerapan tenaga kerja sektor informal sebesar $24,22 \%$. Variabel puk menunjukkan dampak yang signifikan pada tingkat kesalahan $10 \%$ terhadap penyerapan tenaga kerja, setiap kenaikan penduduk usia kerja sebesar satu persen akan menambah penyerapan tenaga kerja sektor formal sebesar $14,45 \%$. Sementara variabel ak tidak berdampak signifikan, serta variabel $\ln _{\text {_total dan }} \ln$ _pdrb berpengaruh positif dan signifikan, dengan setiap satu persen kenaikan jumlah penduduk yang bekerja akan menambah penyerapan angkatan kerja sektor formal sebesar 69\%, serta setiap satu persen kenaikan PDRB akan berdampak kenaikan variabel dependen sebesar 83,81\%.

\section{b. Hasil Analisis Deskriptif}

Analisis deskriptif digunakan untuk mengetahui sebaran data, baik data pada variabel dependen maupun independen. Sebagaimana persamaan (3) dan (4), variabel dependen dalam persamaan regresi panel adalah ln_ft dan $\ln _{-}$it, begitu juga untuk variabel independen pdrb yang ditransformasi dalam bentuk logaritma. Akan tetapi, dalam analisis deskriptif akan dilihat nilai riil dan bukan dalam bentuk logaritma. Analisis deskriptif dilakukan terhadap masing-masing variabel dengan jumlah observasi sebanyak 702 buah. Rata-rata jumlah tenaga kerja formal untuk seluruh provinsi adalah $255.847,9$ orang yang berarti bahwa setiap provinsi jumlah pekerja sektor formal antara 255.847 hingga 255.848 orang. Sedangkan rata-rata jumlah pekerja sektor informal sebanyak $247.411,2$ orang. Statistik deskriptif menunjukkan bahwa rata-rata pekerja formal lebih banyak dibandingkan dengan pekerja informal. Akan tetapi, nilai minimum untuk kedua variabel relatif tidak berbeda dengan sektor informal memiliki jumlah pekerja lebih banyak. Pada sisi lain, nilai maksimum variabel ft jauh lebih banyak dibandingkan dengan sektor informal. Hal ini menunjukkan bahwa secara rata-rata pekerja sektor formal di pulau Jawa masih lebih banyak dibandingkan pekerja sektor informal.

TABEL-3. Statistik Deskriptif Variabel Dependen dan Independen

\begin{tabular}{lrcrr}
\hline Variabel & $\begin{array}{c}\text { Jumlah } \\
\text { Observasi }\end{array}$ & Rata-rata & Min & Max \\
\hline$f t$ & 702 & $255.847,9$ & 5946 & 1.486 .174 \\
\hline$i t$ & 702 & $247.411,2$ & 3552 & 832.411 \\
\hline$p d r b$ & 702 & 38489,24 & 2026 & 354882 \\
\hline$a k$ & 702 & $517.292,9$ & 111063 & 2.026 .976
\end{tabular}

Catatan: Dari hasil pengolahan data regresi data panel fixed effect menggunakan Eviews 8

Tabel 4 merupakan tabel deskriptif mengenai total angkatan kerja berdasarkan provinsi dan tahun. Dari keenam provinsi sebagai daerah sampel dapat diketahui bahwa total angkatan kerja tertinggi berada di Provinsi Jawa Timur sejak tahun 2010 hingga 2015, sedangkan jumlah terendah ada di DI Yogyakarta. Secara keseluruhan angkatan kerja mengalami peningkatan dari tahun ke tahun, kecuali pada tahun 2014 ke 2015 yang mengalami penurunan, meskipun peningkatan dan penurunan yang terjadi relatif tidak terlalu tajam. Dilihat dari polanya, Jakarta sebagai magnet dalam perekonomian di Indonesia mengalamai peningkatan jumlah angkatan kerja yang signifikan pada tahun 2011 
ke 2012. Sedangkan peningkatan cukup signifikan di Provinsi Jawa Barat terjadi pada tahun 2013 ke 2014 . Peningkatannya tidak berlanjut pada tahun 2015, karena jumlah angkatan kerja justru menurun pada tahun tersebut dan hal tersebut terjadi di hampir seluruh provinsi. Fenomena migrasi angkatan kerja antara tahun 2014 dan 2015 turut berpengaruh pada jumlah total angkatan kerja di Pulau Jawa. Patut dicermati faktor-faktor yang menjadi penyebab angkatan kerja bermigrasi keluar pada tahun-tahun tersebut.

TABEL-4. Statistik Deskriptif Total Angkatan Kerja Berdasarkan Provinsi dan Tahun

\begin{tabular}{lccrrrr}
\hline \multirow{2}{*}{ Provinsi } & \multicolumn{7}{c}{ Tahun } \\
\cline { 2 - 7 } & \multicolumn{1}{c}{2010} & 2011 & 2012 & 2013 & \multicolumn{1}{c}{2014} & 2015 \\
\hline DKI Jakarta & 6.130 .302 & 6.095 .296 & 6.427 .202 & 6.245 .562 & 6.255 .811 & 6.556 .636 \\
\hline Jawa Barat & 14.398 .807 & 14.798 .939 & 15.453 .054 & 15.515 .485 & 16.286 .345 & 15.565 .867 \\
\hline Jawa Tengah & 14.538 .203 & 14.681 .158 & 14.782 .022 & 14.781 .155 & 15.082 .956 & 14.967 .772 \\
\hline DI Yogyakarta & 1.634 .029 & 1.689 .168 & 1.741 .336 & 1.692 .993 & 1.835 .971 & 1.767 .094 \\
\hline Jawa Timur & 17.698 .114 & 17.935 .862 & 18.083 .527 & 18.291 .022 & 18.242 .327 & 18.306 .579 \\
\hline Banten & 4.184 .960 & 4.195 .171 & 4.236 .962 & 4.198 .191 & 4.450 .899 & 4.392 .813 \\
\hline Total & 58.584 .415 & 59.395 .594 & 60.724 .103 & 60.724 .408 & 62.154 .309 & 61.556 .761 \\
\hline
\end{tabular}

Catatan: Dari hasil pengolahan data Sakernas BPS Tahun 2010-2015 dengan menyertakan penimbang

Jika dilihat berdasarkan tahun, fluktuasi jumlah pekerja sektor formal dan informal relatif sama. Tahun 2010 hingga tahun 2011 total jumlah pekerja sektor informal selalu lebih besar dibandingkan dengan sektor informal. Tahun 2012 tren kenaikan pekerja sektor formal mulai melebihi sektor informal dan terus terjadi hingga 2015. Tahun 2013 ke tahun 2014 pekerja sektor informal cenderung mengalami kenaikan, akan tetapi dari segi persentase tetap tidak dapat melebihi pekerja sektor formal. Hal ini tentunya tidak sesuai dengan pernyataan dalam penelitian yang dilakukan oleh Bosch dan Esteban-Pretel (2012) yang menemukan bahwa jumlah pekerja sektor informal di negara berkembang dapat mencapai $70 \%$.

Jika rata-rata dirinci berdasarkan provinsi, DKI Jakarta merupakan provinsi yang memiliki rata-rata jumlah pekerja sektor formal yang jauh lebih besar dibandingkan dengan provinsi-provinsi lainnya selama tahun 2011 hingga 2015. Sedangkan provinsi-provinsi lain relatif sama dan pola fluktuasinya juga nyaris sama selama jangka waktu yang sama pula. DKI Jakarta dengan hampir keseluruhan wilayahnya adalah perkotaan memang menjadi ciri khas tingginya pekerja sektor formal ini (BPS, 2016). Di samping itu, total pekerja di Jakarta juga cukup tinggi sehingga jumlah absolutnya cukup signifikan jika dibandingkan dengan wilayah-wilayah lain. Faktor DKI Jakarta sebagai penarik urbanisasi juga dapat dijadikan pertimbangan mengapa hal ini bisa terjadi.

GAMBAR - 1. Rata-rata pekerja sektor formal berdasarkan tahun dan provinsi

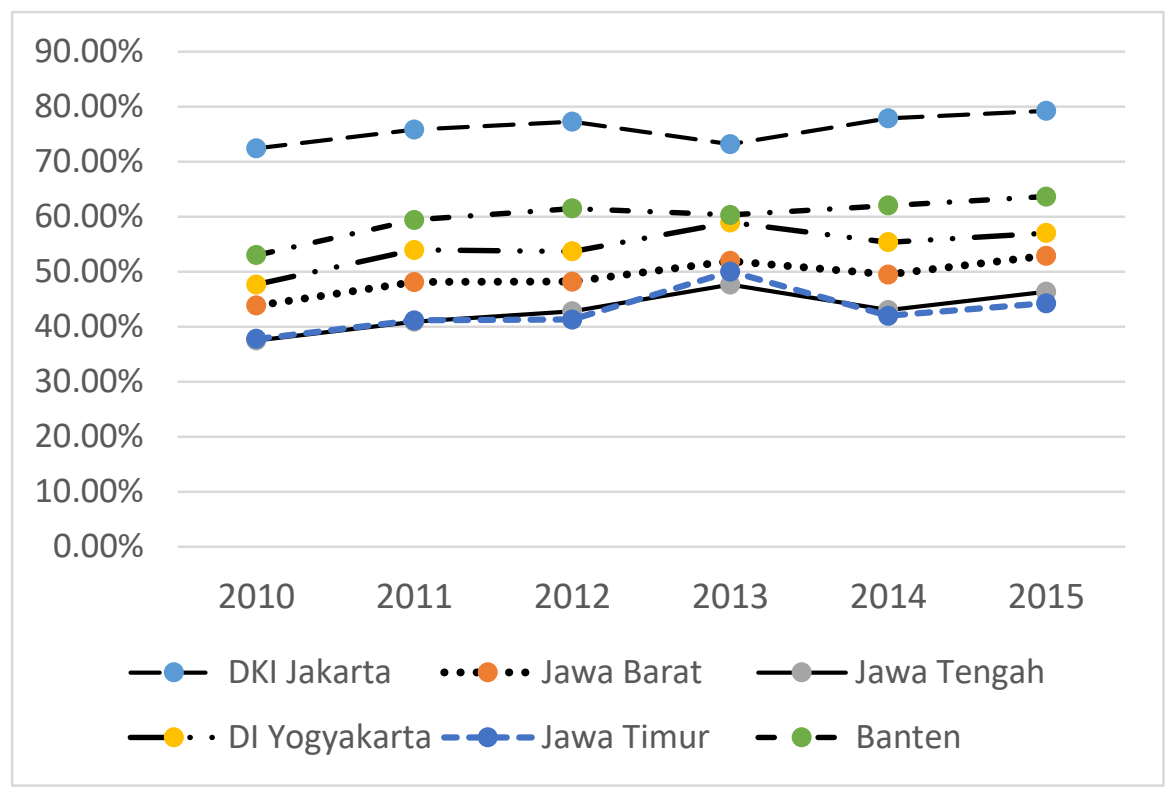


Catatan: Dari rata-rata pekerja sektor formal berdasarkan tahun dan provinsi menggunakan data Sakernas BPS

Tahun 2010-2015

Hasil yang cukup mengejutkan terdapat pada sektor informal, dengan total pekerja sektor informal tertinggi berada di Provinsi Jawa Timur. Banten dengan proporsi angkatan kerja yang relatif lebih besar dibandingkan dengan provinsi-provinsi lain di Pulau Jawa ternyata memiliki jumlah pekerja sektor informal yang lebih tinggi. Sedangkan jumlah pekerja sektor informal paling sedikit berada di DKI Jakarta. Pola fluktuasi yang terjadi relatif sama dari tahun ke tahun sejak 2011 hingga 2015.

GAMBAR-2. Rata-rata pekerja sektor informal berdasarkan tahun dan provinsi

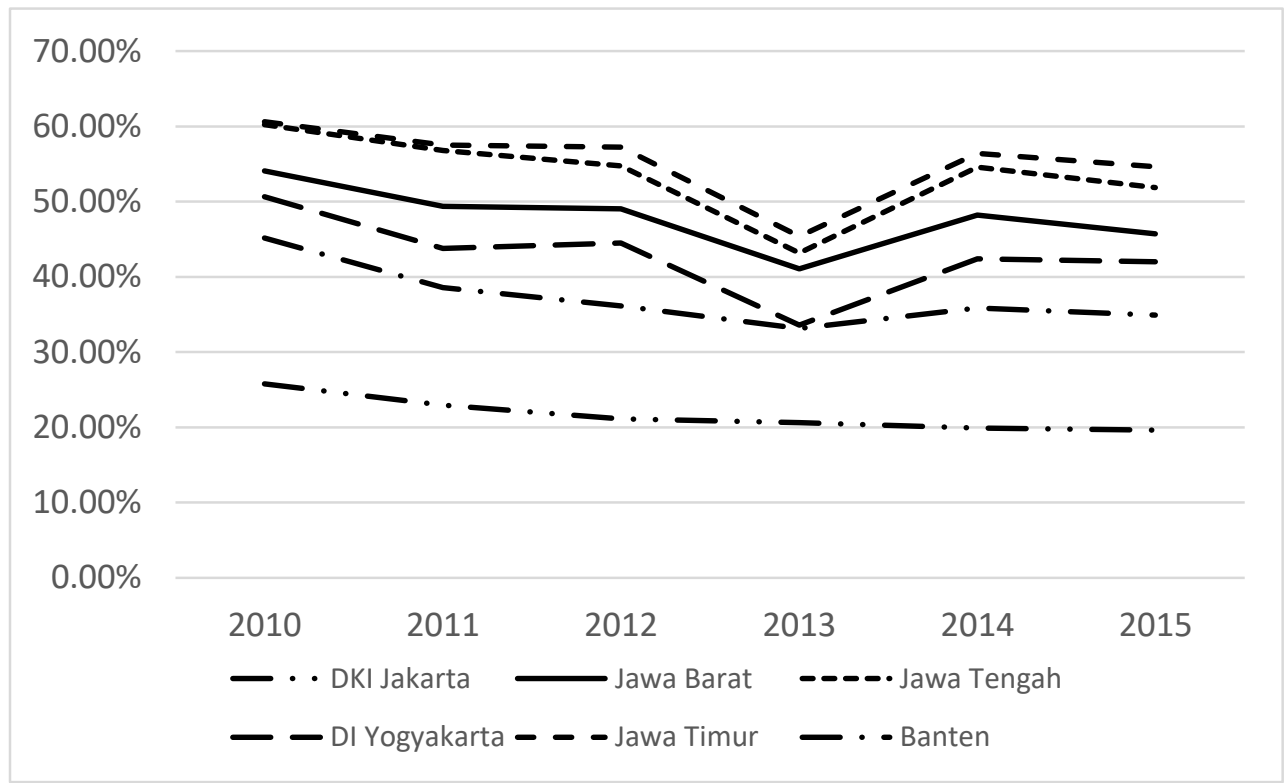

Catatan: Dari rata-rata pekerja sektor informal berdasarkan tahun dan provinsi menggunakan data Sakernas BPS Tahun 2010-2015

\section{c. Pembahasan}

Analisis empiris memperlihatkan pengaruh pemilihan kepala daerah tingkat kabupaten/kota signifikan terhadap jumlah tenaga kerja baik sektor formal maupun yang informal. Pengaruh yang terjadi berlawanan antara sektor informal dan formal. Pilkada kabupaten/kota berpengaruh negatif terhadap tenaga kerja sektor formal, akan tetapi sebaliknya berpengaruh positif terhadap penyerapan sektor informal. Seperti yang telah diduga dalam teori, sektor informal merupakan sektor yang lebih mudah untuk diintervensi karena sektor ini merupakan unregulated sector yang cenderung tidak terikat oleh aturan-aturan pemerintah.

Di sisi lain, pilkada tingkat provinsi tidak berpengaruh pada penyerapan tenaga kerja baik di sektor formal dan informal. Hal ini memang agak mengejutkan, tetapi jika ditinjau dari daerah jangkauan, pilkada provinsi memang lebih luas dan kemungkinan untuk fokus menjadi sulit. Pada saat pilkada diadakan bersamaan antara kabupaten/kota dan provinsi, penyerapan sektor informal cenderung menurun, dan sebaliknya justru meningkat di sektor formal. Hal ini sesuai dengan hasil penelitian yang dilakukan oleh Mechtel dan Potrafke (2013), yaitu calon kepala pemerintahan selalu memiliki motif dan pengaruh terhadap pasar kerja. Bentuk politisasi tersebut selalu menjadikan pengangguran sebagai obyek. Lebih spesifik dalam penelitian ini juga menunjukkan bahwa sektor tenaga kerja yang dijadikan obyek oleh calon kepala daerah adalah sektor informal. Penelitian ini juga memberikan gambaran lain bahwa kondisi ketenagakerjaan di negara berkembang relatif berbeda dengan di negara maju, meskipun secara keseluruhan dampak yang ditimbulkan relatif sama.

Ditinjau dari keikutsertaan calon petahana, calon petahana berdampak signifikan pada sektor informal.Pada saat calon petahana kembali mencalonkan diri penyerapan tenaga kerja sektor informal menjadi lebih besar, hal yang serupa tidak terjadi pada sektor informal. Sjahrir, Kis-Katos, \& Schulze (2013) menemukan bahwa pengaruh dari PBC untuk di wilayah Indonesia hanya terjadi pada saat pemilihan secara langsung, dan tidak terjadi pada pemilihan 
secara tidak langsung, serta pengaruhnya lebih besar pada saat calon petahana kembali mencalonkan diri. Temuan lain yang ditunjukkan dalam penelitian ini adalah bahwa dalam pilkada provinsi dan kabupaten/kota memiliki dampak yang berbeda, bahkan saat kedua pilkada dilakukan pada saat yang bersamaan. Hal ini menunjukkan bahwa ada banyak fenomena kompleks yang timbul akibat adanya pelaksanaan pilkada, bukan hanya dari sisi ekonomi saja. Rinakit (2005) menemukan bahwa dari observasi sebanyak 90 daerah, dengan rincian 4 provinsi dan 86 kabupaten/kota mengindikasikan bahwa pilkada di Indonesia tidak lebih dari sekedar unjuk kekuatan masingmasing kekuatan politik di daerah. Kekuatan yang ditunjukkan termasuk di dalamnya politik uang.

Penelitian ini mencoba menyoroti dan berusaha menjelaskan serta membuktikan sebuah paradoks dalam politik lokal Indonesia kontemporer: yaitu, melemahnya pengaruh partai politik dalam perubahan politik lokal, hal itu terindikasi dari usaha untuk mempertahankan monopoli dan memperkuat hegemoni atas pencalonan kandidat untuk pemerintah daerah, dengan terus mempertahankan dominasinya di daerah kekuasaan. Temuan Choi (2011) juga mengindikasikan hal serupa, pilkada di Indonesia tidak lebih dari mempertahankan dominasi dan bahkan membentuk dinasti politik di suatu daerah. Di beberapa wilayah di Indonesia, gerakan kekerasan dimobilisasi melawan musuh etnis, apakah musuh-musuh ini adalah komunitas yang saingan (seperti konflik komunal di Kalimantan Barat dan Tengah dan Maluku Utara) atau negara (seperti dalam gerakan separatis di Aceh dan Papua) (Aspinall, 2011).

\section{SIMPULAN}

Analisis empiris memperlihatkan pengaruh pemilihan kepala daerah tingkat kabupaten/kota signifikan terhadap jumlah tenaga kerja, baik sektor formal maupun yang informal. Pengaruh yang terjadi berlawanan antara sektor informal dan formal. Pilkada kabupaten/kota berpengaruh negatif terhadap penyerapan tenaga kerja sektor formal, akan tetapi sebaliknya berpengaruh positif terhadap penyerapan sektor informal. Seperti yang telah diduga dalam teori, sektor informal merupakan sektor yang lebih mudah untuk diintervensi karena sektor ini merupakan unregulated sector yang cenderung tidak terikat oleh aturan-aturan pemerintah.

Di sisi lain, pilkada tingkat provinsi tidak berpengaruh pada penyerapan tenaga kerja baik di sektor formal dan informal. Hal ini memang agak mengejutkan, tetapi jika ditinjau dari daerah jangkauan, pilkada provinsi memang lebih luas dan kemungkinan untuk fokus menjadi sulit. Pada saat pilkada diadakan bersamaan antara kabupaten/kota dan provinsi, penyerapan sektor informal cenderung menurun, dan sebaliknya justru meningkat di sektor formal. Ditinjau dari keikutsertaan calon petahana, calon petahana berdampak signifikan pada sektor informal. Pada saat calon petahana kembali mencalonkan diri penyerapan tenaga kerja sektor informal menjadi lebih besar, hal yang serupa tidak terjadi pada sektor informal

\section{DAFTAR PUSTAKA}

Aspinall, E., (2011), Democratization and Ethnic Politics in Indonesia: Nine Theses. Journal of East Asian Studies, 1l, 289-319.

Badan Pusat Statistik (BPS). (2016). Indikator Pasar Tenaga Kerja Indonesia Agustus 2016. Jakarta: Badan Pusat Statistik Indonesia.

Bosch, M., \& Esteban-Pretel, J. (2012). Job creation and job destruction in the presence of informal markets. Journal of Development Economics, 98(2), 270-286.

Charles, K. K., \& Stephens, M. (2013). Employment, Wages, and Voter Turnout. American Economic Journal: Applied Economics, 5(4), 11l-143.

Choi, N. (2011). Local politics in Indonesia : pathways to power. Routledge contemporary Southeast Asia series.

Coelho, C., Veiga, F. J., \& Veiga, L. G. (2006). Political business cycles in local employment: Evidence from Portugal, Economics Letters, 93(1), 82-87.

Dahlberg, M., \& Mörk, E. (2011). Is there an election cycle in public employment? Separating time effects from election year effects. CESifo Economic Studies, 57(3), 480-498. https://doi.org/10.1093/cesifo/ifr003

Drazen, A., \& Eslava, M. (2006). Pork Barrel Cycles. NBER Working Papers, 53, 1689-1699.

Hagedorn, M., Karahan, F., Manovskii, I., \& Mitman, K. (2013). Unemployment benefits and unemployment in the great recession: the role of macro effects. NBER Working Papers 19499.

Hohberg, M., \& Lay, J. (2015). The impact of minimum wages on informal and formal labor market outcomes: evidence from Indonesia, IZA Journal of Labor \& Development, 4(1), l-25. 
Hussmanns, R. (2004). Defining and measuring informal employment, International Labour Organization Website. Retrieved from http://www.ilo.org/public/english/bureau/stat/download/papers/meas.pdf.

Khemani, S. (2004). Political cycles in a developing economy: Effect of elections in the Indian States. Journal of Development Economics, 73(1), 125-154.

Lewis-Beck, M. S., \& Paldam, M. (2000). Economic voting: an introduction. Electoral Studies, 19(2-3), 113-121. http://dx.doi.org/10.1016/S0261-3794(99)00042-6

Mankiw, N. G., (2001). The Inexorable and Mysterious Tradeoff between Inflation and Unemployment, The Economic Journal, 111(471), C45-C61. https://doi.org/10.1111/1468-0297.00619

Mechtel, M., \& Potrafke, N. (2013). Electoral cycles in active labor market policies. Public Choice, 156(1-2), 181-194.

Mueller, D. C. (2003). Public Choice III. Cambridge: Cambridge University Press.

Nordhaus, W. D. (1975). The Political Business Cycle. The Review of Economic Studies. https://doi.org/10.2307/2296528

Park, A., Wu, Y., \& Du, Y. (2012). Informal Employment in Urban China: Measurement and Implications. Washington DC: World Bank.

Peraturan Komisi Pemilihan Umum (KPU) RI No. 3 tahun 2016 tentang Tahapan, Program, dan Jadwal Penyelenggaraan Pemilihan Gubernur dan Wakil Gubernur, Bupati dan Wakil Bupati, dan/atau Walikota dan Wakil Walikota Tahun 2017

Rogoff, K. (1990). Equilibrium Political Budget Cycles. The American Economic Review, 80(1), 21-36.

Rinakit, S. (2005). Indonesian Regional Elections In Praxis. Nanyang Technological University, Singapore.

Shi, M., \& Svensson, J. (2006). Political budget cycles: Do they differ across countries and why?. Journal of Public Economics, 90(8-9), 1367-1389.

Sjahrir, B. S., Kis-Katos, K., \& Schulze, G. G. (2013). Political budget cycles in Indonesia at the district level. Economics Letters, 120(2), 342-345.

Ulyssea, G. (2010). Regulation of entry, labor market institutions and the informal sector. Journal of Development Economics, 91(1), 87-99.

Wooldridge, J. M. (2002). Econometric Analysis of Cross Section and Panel Data. Booksgooglecom, 58(2), p. 752. 